\title{
Vertical distribution and pigment composition of a picoplanktonic prochlorophyte in the subtropical North Atlantic: a combined study of HPLC- analysis of pigments and flow cytometry
}

\author{
Marcel J. W. Veldhuis, Gijsbert W. Kraay \\ Netherlands Institute for Sea Research, PO Box 59, 1790 AB Den Burg, The Netherlands
}

\begin{abstract}
During a survey in the subtropical North Atlantic along $20^{\circ} \mathrm{W}$ longitude, up to 95000 cells $\mathrm{ml}^{-1}$ of an unknown picoplankter were observed. The species was identified as a prochlorophyte, sensu Chisholm et al. (1988), by shipboard flow-cytometry and HPLC-analysis of pigment composition. Enumeration of the picoplankton groups indicated that these prochlorophyte-like cells contributed most to the deep chlorophyll maximum (situated at 80 to $100 \mathrm{~m}$ ). They were, however, also abundant in the upper water layers. The cellular content of their major pigments ('red shifted' or divinyl chlorophyll $a$, chlorophyll $b$ and zeaxanthin) varied considerably over the water column and appeared to be dependent on the growth irradiance. The 'red-shifted' chlorophyll a concentration increased from $0.91 \mathrm{fg} \mathrm{cell}^{-1}$ near the surface to $5.4 \mathrm{fg} \mathrm{cell}^{-1}$ near the base of the euphotic zone $\left(0.3 \% \mathrm{I}_{0}\right)$; chlorophyll $b$ from $0.44 \mathrm{fg}$ cell $^{-1}$ to $8.20 \mathrm{fg} \mathrm{cell}^{-1}$. The zeaxanthin concentration per cell remained almost constant with respect to depth (average $1.97 \pm 0.15 \mathrm{fg}_{\text {cell }}^{-1}$ ). A linear relationship was found between the sum of 'red-shifted' chlorophyll $a$ and chlorophyll $b$ and the flow-cytometrically obtained mean red fluorescence signal of the algal cell.
\end{abstract}

\section{INTRODUCTION}

Recent research devoted to the taxonomy and abundance of picophytoplankton has resulted in the description of a variety of taxonomic classes (Stockner \& Antia 1986, Stockner 1988). Because of the small size of these organisms ( 0.2 to $2.0 \mu \mathrm{m})$, light microscopy has often been supplemented by epifluorescence microscopy, chromatographic analysis of pigments (Gieskes \& Kraay 1986, Hooks et al. 1988), electron microscopy (Johnson \& Sieburth 1982, Takahashi \& Hori 1984), immunofluorescence techniques (Campbell \& Iturriaga 1988, Shapiro et al. 1989) and flow cytometry (Olson et al. 1985, Chisholm et al. 1988, Olson et al. 1990).

Recently Chisholm et al. (1988) employed flowcytometric analysis to identify a new member of a primitive prokaryotic, picoplanktonic group, the Prochlorophyta. The discovery of this prochlorophyte is analogous to the discovery of a free-living freshwater Prochloron in a Dutch lake by Burgers-Wiersma et al. (1986). The marine prochlorophyte appeared to be most abundant at the deep chlorophyll maximum of oligotrophical tropical waters with zeaxanthin, chlorophyll $b$ and a unique derivative of chlorophyll $a$, tentatively identified as a divinyl-like chlorophyll $a$, as major pigments (Chisholm et al. 1988). This divinyl-like chlorophyll a showed close resemblance to the socalled 'red-shifted' chlorophyll a described earlier by Gieskes \& Kraay $(1983,1986)$. The flow-cytometric signal obtained by Chisholm et al. (1988) indicated that the prochlorophytes dominated in the deeper water layers, but in subsequent studies, after increasing the sensitivity of the flow cytometer, they could also be found near the surface (Olson et al. 1990). In addition the typical 'red-shifted' chlorophyll $a$, which is characteristic of these marine prochlorophytes, was also found abundantly in the upper water layers of the oceans in numerous places (Gieskes et al. 1978, Gieskes \& Kraay 1983, 1986).

During our contribution to the Joint Global Ocean Flux Study (JGOFS), vertical hydrographical profiles were made along $20^{\circ} \mathrm{W}$ and water samples taken in the subtropical North Atlantic Ocean ( 37 to $\left.33^{\circ} \mathrm{N}\right)$. Direct shipboard observations by epifluorescence microscopy, 
HPLC-analysis of pigments and flow cytometry indicated the presence of not only chroococcoid cyanobacteria, but also prochlorophyte-like phytoplankton (cf. Chisholm et al. 1988). In the present paper we describe the vertical distribution and light-dependent variations in cellular pigment of these prochlorophytes.

\section{MATERIAL AND METHODS}

The study was conducted in the northeastern Atlantic Ocean during August and September 1989. In total, 72 stations were sampled between 33 and $37^{\circ} \mathrm{N}$ along $20^{\circ} \mathrm{W}$. Vertical profiles of temperature, salinity, in situ fluorescence and quantum irradiance (Licor, spherical sensors) were routinely measured in the upper $150 \mathrm{~m}$. Water samples from discrete depths were taken predawn with Go-Flo bottles (12 1). Subsamples for nutrient determinations were immediately analyzed using Technicon Auto-Analyzers. For nitrate analysis a low level (10 to $100 \mathrm{nmol}^{-1}$ ) module was used.

Flow cytometry. Phytoplankton cell counts and scatter vs fluorescence signatures of the various groups of particles and algae present were obtained by means of an EPICS CS flow cytometer. The laser emission varied from 1000 to $1250 \mathrm{~mW}$ at a wavelength of $488 \mathrm{~nm}$. The set-up of the photomultipliers was defined to quantify the red fluorescence of the chlorophylls (656 to $700 \mathrm{~nm}$ ) and the orange fluorescence ( 530 to $590 \mathrm{~nm}$ ) of phycoerythrin (Olson et al. 1985, Burkill 1987, Olson et al. 1990). Duplicate samples of up to $1 \mathrm{ml}$ were counted, followed by a rinsing and washing twice with $0.2 \mathrm{ml}$ of $0.2 \mu \mathrm{m}$ filtered seawater to ensure that no particles were retained in the cuvette or tubing. Scatter and fluorescence settings and signals were calibrated with standard fluorescence beads ( 3.0 and $0.88 \mu \mathrm{m}$; Polysciences, Inc.). All samples were stored in the dark and kept cool on melting ice prior to counting, which took place within $2 \mathrm{~h}$ of sampling.

Pigment analysis. To determine the concentrations of the major chlorophylls and carotenoid pigments, samples of up to 18.51 were filtered through $47 \mathrm{~mm}$ glassfibre filters (Whatman GF/F), and occasionally for size class determination through $3,1.0,0.6$ and $0.4 \mu \mathrm{m}$ Nuclepore membrane filters. Filters were immediately extracted on board using a Braun-Melsung, $\mathrm{CO}_{2}$ cooled homogeniser (20 s) in $5 \mathrm{ml}$ methanol containing $2 \%$ of ammonium acetate. Prior to injection the extract was filtered over a $10 \mathrm{~mm}$ GF/F glassfibre filter.

Normal and reverse-phase HPLC-analysis was carried out according to the methods described by Abaychi \& Riley (1979) and Gieskes \& Kraay (1988). For normal-phase chromatography a column of $150 \times$ $4.6 \mathrm{~mm}$, packed with Rosil $5 \mu \mathrm{m}$, was used. The solvent was a mixture of light petroleum, acetone, dimethyl- sulfoxide and diethylamine in the ratio $75: 23.25: 1.5$ : 0.25 by volume, with a flow rate of $1 \mathrm{ml} \mathrm{min}^{-1}$. Reversephase HPLC was performed on a Rosil C18 column $(150 \times 4.6 \mathrm{~mm})$ equilibrated with $0.02 \mathrm{M}$ ammonium acetate in $80 \%$ methanol and eluted with a linear gradient of 0 to $100 \%$ of ethyl acetate/methanol (30/70, $\mathrm{v} / \mathrm{v}$ ) at a flow rate of $0.8 \mathrm{ml} \mathrm{min}^{-1}$ over a period of 20 min. Absorption of pigments was detected at 436 and $658 \mathrm{~nm}$, respectively. The normal phase HPLC set-up was used to separate 'normal' chlorophyll a from 'redshifted' chlorophyll $a$. Part of the extract was transferred from methanol to diethyl ether, by adding an equal volume of diethyl ether and shaking it with a volume of $10 \% \mathrm{NaCl}$ solution at least 10 times larger than that of the methanol extract (Jeffrey 1968). The diethyl ether layer was concentrated by means of vacuum evaporation and dried by adding a few crystals of $\mathrm{NaCl}$. Peak areas were translated into units of weight using the following extinction coefficients:

$$
\begin{aligned}
& \text { (90\% acetone) } \\
& \mathrm{E}_{664 \mathrm{~nm}}: 87.7\left(\mathrm{~L} \times \mathrm{g}^{-1} \times \mathrm{cm}^{-1}\right) \\
& \text { chlorophyll } b \text { (90\% acetone) } \\
& \mathrm{E}_{647 \mathrm{~nm}}: 51.4\left(\mathrm{~L} \times \mathrm{g}^{-1} \times \mathrm{cm}^{-1}\right) \\
& \text { zeaxanthin (ethanol) } \\
& \mathrm{E}_{448 \mathrm{~nm}}: 254\left(\mathrm{~L} \times \mathrm{g}^{-1} \times \mathrm{cm}^{-1}\right)
\end{aligned}
$$$$
\text { chlorophyll } a \text { and 'red-shifted' chlorophyll a }
$$

The concentration of 'red-shifted' chlorophyll a was estimated using the ratio of the peak heights detected at $658 \mathrm{~nm}$ of the 2 chlorophylls as separated by means of the normal phase and total amount of chlorophyll with the reverse phase set-up.

\section{RESULTS AND DISCUSSION}

The hydrographical features presented in Fig. 1 are typical of the survey area, and include a sharp thermocline and pycnocline at 20 to $30 \mathrm{~m}$ depth, and nitrogen concentrations (nitrate plus nitrite) ranging from 10 to $100 \mathrm{nmol} 1^{-1}$ in the upper $80 \mathrm{~m}$. Phosphate concentration (data not shown) was ca $40 \mathrm{nmol} \mathrm{l}^{-1}$, with a gradual increase towards the base of the euphotic zone.

An in situ fluorescence maximum was found at 80 to $100 \mathrm{~m}$ depth, which was coincident with the chlorophyll a maximum (Fig. 2). Flow cytometer signatures representing the pico-size class cells (i.e. those passing through a $1 \mu \mathrm{m}$ Nuclepore filter), showed 2 distinct clusters: one caused by orange-fluorescing chroococcoid cyanobacteria (Olson et al. 1985, Olson et al. 1990) and a second distinct cluster of picoplankton which could only be distinguished at depths deeper than the $10 \%$ isolume. The cyanobacteria, most likely Synechococcus spp., were present in relatively low 


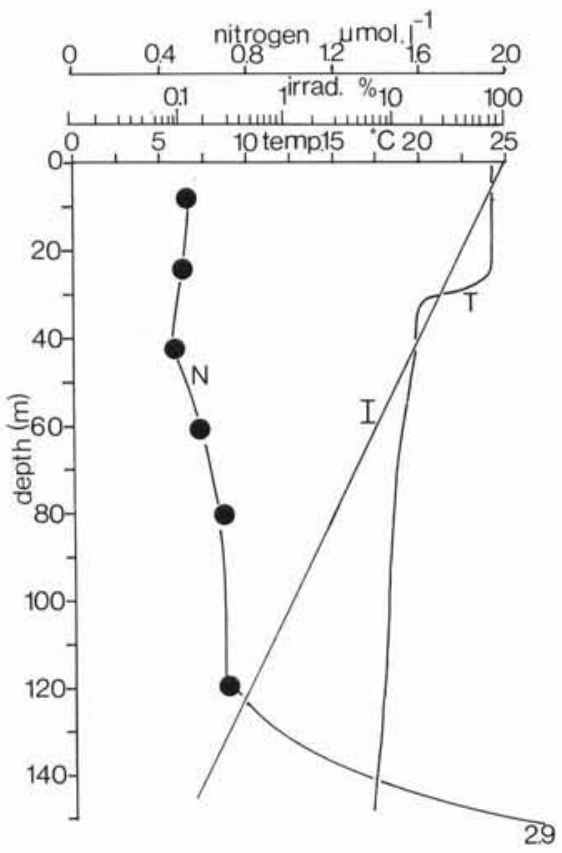

Fig. 1. Depth profile of temperature (T), percentage of incident irradiance (I) and nitrogen ( $\mathrm{N}$; nitrate plus nitrite).

numbers (a few hundred per $\mathrm{ml}$ ) except in the surface water layers where up to $2500 \mathrm{ml}^{-1}$ were found (Fig. 2). The latter cluster consisted of cells which were generally smaller than the cyanobacteria; $25 \%$ of these cells passed through a $0.4 \mu \mathrm{m}$ Nuclepore filter. In contrast, the Synechococcus type cyanobacteria were retained by a $0.6 \mu \mathrm{m}$ Nuclepore filter. HPLC pigment analysis revealed that the $<0.4 \mu \mathrm{m}$ fraction contained the 'redshifted' chlorophyll a described by Gieskes \& Kraay (1983) which, according to Chisholm et al. (1988), is characteristic of the free-living oceanic prochloro- phytes (Fig. 2). In the area surveyed, maximum cell numbers of this algal group varied between 30000 and $95000 \mathrm{ml}^{-1}$, with greatest cell densities always found at depths corresponding to the 2.0 to $0.5 \%$ incident irradiation $\left(\mathrm{I}_{0}\right)$ level.

The HPLC-pigment signatures of phytoplankton samples in the study area revealed that these prochlorophytes were present throughout the water column (Figs. 2 and 3). The HPLC chromatograms showed a close resemblance to those found in tropical and subtropical regions including the Caribbean (Gieskes \& Kraay 1983), the Atlantic Ocean (Gieskes et al. 1978, Gieskes \& Kraay 1986), and the Banda Sea in Indonesia (Gieskes et al. 1988). Although in cell numbers prochlorophytes were the most abundant phytoplankters their 'red-shifted' chlorophyll a contribution to the total amount of chlorophyll a never exceeded $50 \%$ of the samples taken in the area investigated (Fig. 3). Small amounts of other pigments (chlorophyll $c$, chlorophyll $c_{3}$, fucoxanthin, 19'-hexanoyloxyfucoxanthin and 19'butanoyloxyfucoxanthin) were always present but only as traces in the fraction containing particles passing a $1 \mu \mathrm{m}$ filter. Flow-cytometer histograms occasionally showed small numbers of larger phytoplankton, most of them larger than $3.0 \mu \mathrm{m}$ in size.

In calculating the cellular concentrations of the group-specific pigments of the oceanic prochlorophyte ('red-shifted' chlorophyll $a$, chlorophyll $b$ and zeaxanthin) throughout the water column, 2 problems arise. The first is that a direct estimation of prochlorophyte counts in surface waters is not possible. Prochlorophytes were 'identified' and counted flow-cytometrically based on their scatter and red fluorescence (chlorophyll) properties (Fig. 4, lower panel). In general the 2-dimensional (scatter vs red fluorescence) histo-
Fig. 2. Left: Chlorophyll a (O) and 'redshifted' chlorophyll $a(\bullet)$ versus light intensity profile. Right: Total amount of particles (Tot, $\Delta$ ), counted flow-cytometrically, possessing a scatter signature corresponding with that of the picoplankton. Numbers of cyanobacteria (Cyan, *) and prochlorophytes (Proch). For prochlorophytes: (•) directly counted data, where flow-cytometrically achieved histograms showed a distinct cluster; (D) populations where only part of the cells were counted (only part of the cluster was visible); $(0)$ calculated cell numbers derived from total amount of particles (90\% of total amount)
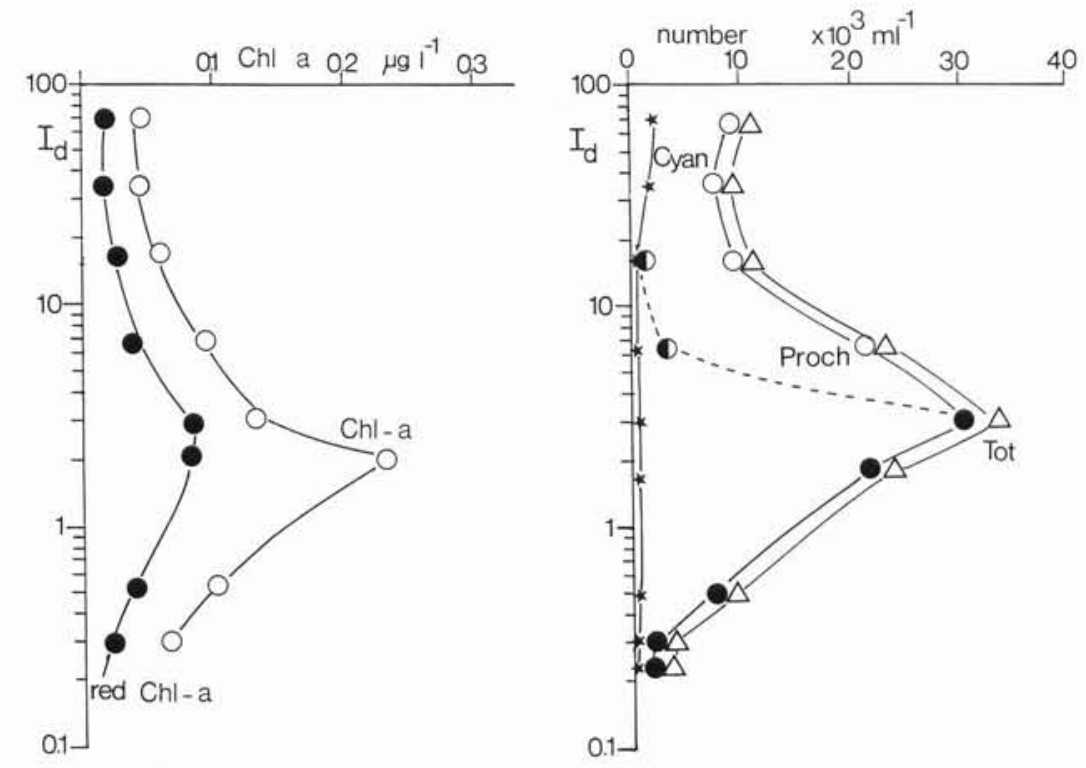
reverse phase
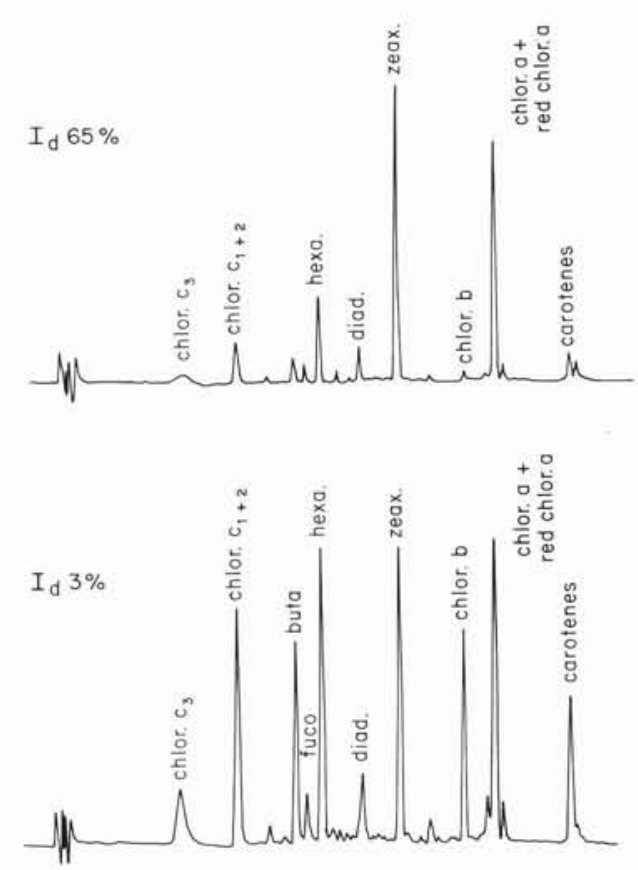

normal phase
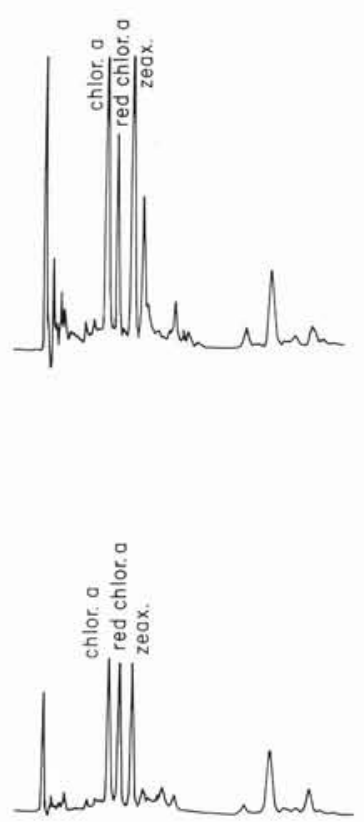

Fig. 3. Two pigment chromatograms, reverseand normal-phase, of whole samples (GF/F glass fibre filters) taken at 65 and $3 \%$ of incident irradiance. For unknown reasons, chlorophyll $b$ did not show a distinct peak when the normalphase set up was used. Chlor, $c_{3}$ : chlorophyll $c_{3}$; chlor. $c_{1+2}$ : chlorophyll $c_{1+2}$; buta: $19^{\prime}$-butanoyloxyfucoxanthin; fuco: fucoxanthin; hexa: $19^{\prime}$ hexanoyloxyfucoxanthin; diad: diadinoxanthin; zeax: zeaxanthin; chlor. b: chlorophyll $b$; chlor. a: chlorophyll $a_{i}$ red chlor. a: 'red-shifted' chlorophyll $a$; carotenes: $\alpha$ and $\beta$ carotene grams showed a distinct cluster of cells, well separated from background noise and other phytoplankton species. Toward the surface, the red fluorescence signal decreased to a level where it can hardly, or not at all, be distinguished from the background noise (Figs. 4 and 5). Therefore, the conventional means of discriminating between picoplankton and other particles, using red fluorescence as the principal discriminator, cannot be applied under these circumstances. However, a more precise examination of the scatter signals (i.e. from deeper in the water column), did show a close relationship between the abundance of particles and the number of picoplankters (Fig. 2). On average, the contribution of picoplankton to the total number of particles having a size of less than $1.0 \mu \mathrm{m}$ was $\geq 95 \%$ (Fig. 2). After a correction for the contribution of cyanobacteria and assuming that the contribution of the prochlorophytes to the total number of particles was $90 \%$, an extrapolation of cell numbers in oceanic surface waters was made (Fig. 2). As shown in Fig. 2, the numbers obtained for the prochlorophytes in the upper $45 \mathrm{~m}$ were on the order of $10000 \mathrm{ml}^{-1}$. This implies that the prochlorophytes not only dominate in deeper waters but also outnumber the cyanobacteria in surface waters. At this particular station the number of prochlorophytes in the upper water column accounted for about one third of the maximum number observed. Assuming a average cell diameter of $0.6 \mu \mathrm{m}$ and a cellular carbon content proportional to the volume fraction, when compared with chroococcoid cyanobacteria (0.294 pg C cell ${ }^{-1}$; Cuhel \& Waterbury 1984) a cellular carbon content for the prochlorophytes of $0.124 \mathrm{pg} \mathrm{C}$ cell $^{-1}$ was estimated. For the larger eukaryotic ultraplankton we used a average cell diameter of $5.0 \mu \mathrm{m}$ and a carbon/cell volume ratio of $0.25 \mathrm{pg} \mathrm{C} \mu \mathrm{m}^{-3}$ (Strathmann 1967). At this particular station the proportion of prochlorophytes to the total phytoplankton carbon biomass is restricted to at most $60 \%$.

The second problem concerns the accurate estimation of the cellular pigment concentration. Whereas chlorophyll $b$ and especially the 'red-shifted' chlorophyll a containing picoplankton are typical of the prochlorophytes (Chisholm et al. 1988), the carotenoid zeaxanthin is also found in the marine chroococcoid cyanobacteria (Alberte et al. 1984, Guillard et al. 1985) as well as some prasinophytes (Foss et al. 1984). To calculate the cellular zeaxanthin content of the prochlorophytes, concentrations were corrected for contributions by cyanobacteria. Laboratory experiments performed with cultures of Synechococcus sp. (clone WH7803, DC2), grown over an irradiance range of 30 to $2000 \mu$ Einst. $\mathrm{m}^{-1} \mathrm{~s}^{-1}$, revealed that this cyanobacterium displayed a constant zeaxanthin concentration of $1.8 \mathrm{fg}$ cell $^{-1}$ (Kana et al. 1988). This value might be slightly underestimated because light quality effects were not taken into account (Bidigare et al. 1989). Fortunately, in most of our samples the numbers of cyanobacteria were rather low (Fig. 2), so the zeaxanthin contribution by this taxonomic group (assuming a concentration of $1.8 \mathrm{fg} \mathrm{cell}^{-1}$ ) was negligible.

Combining both directly and indirectly estimated cell numbers with HPLC-determined pigment concen- 


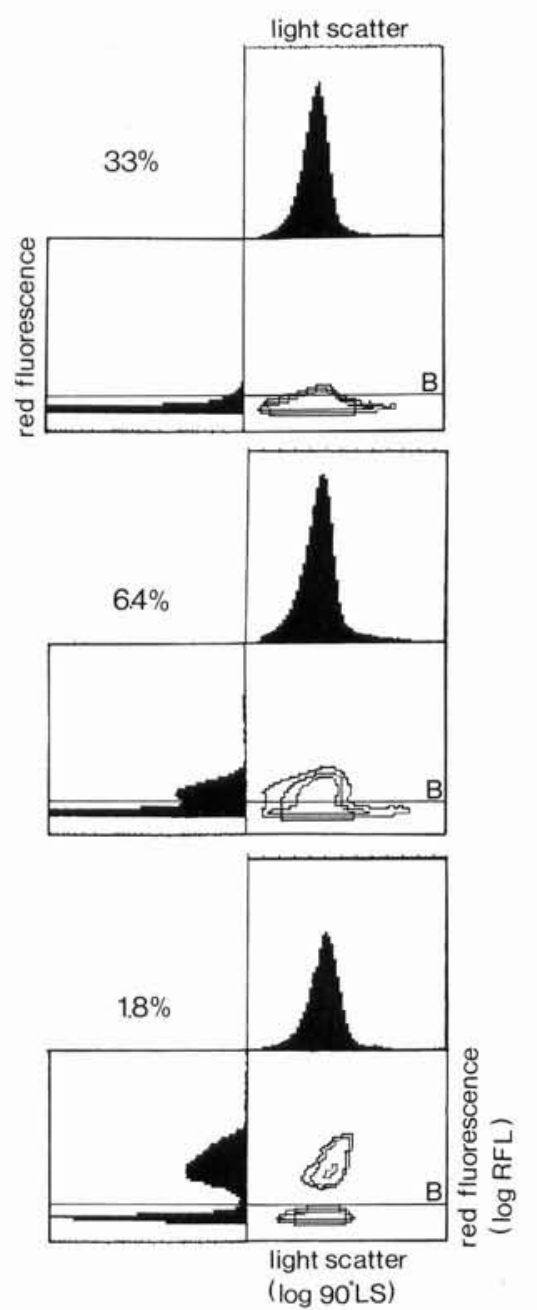

Fig. 4. Two-dimensional flow-cytometer histograms, showing scatter (log 90LS) vs red fluorescence (log RFL, within a range of 656 to $700 \mathrm{~nm}$ ), and a 1-dimensional projection of the 2dimensional histogram, of samples taken at 3 different light intensities $(33,6.4$ and $1.8 \%$ of incident irradiance level). In all 3 cases prochlorophytes were present, as seen from HPLCanalysis of the pigments. The bottom histogram shows a distinct cluster of cells, possessing a distinct fluorescence and scatter signal. The second histogram shows a cluster where the fluorescence of the algal cells is reduced, as a result of a declining pigment content. Only part of the fluorescence signal is above the level of (electronic) background noise (B). The upper histogram shows, due to a further reduction of the pigment content, no distinct cluster of algal cells. Note that in all 3 histograms the scatter signal indicative of the total number of particles (in each case 10000 counted per run) is almost identical

trations for the prochlorophytes, 2 obvious trends were evident in the cell-specific pigment distributions (Fig. 5). The first is that the zeaxanthin content remains fairly constant over the euphotic zone (average of 1.97 $\pm 0.15 \mathrm{fg} \mathrm{cell}^{-1}$ ), thus showing a similar behaviour as recently described for Synechococcus sp. (clone WH7803; Kana et al. 1988). Secondly, both the 'red-

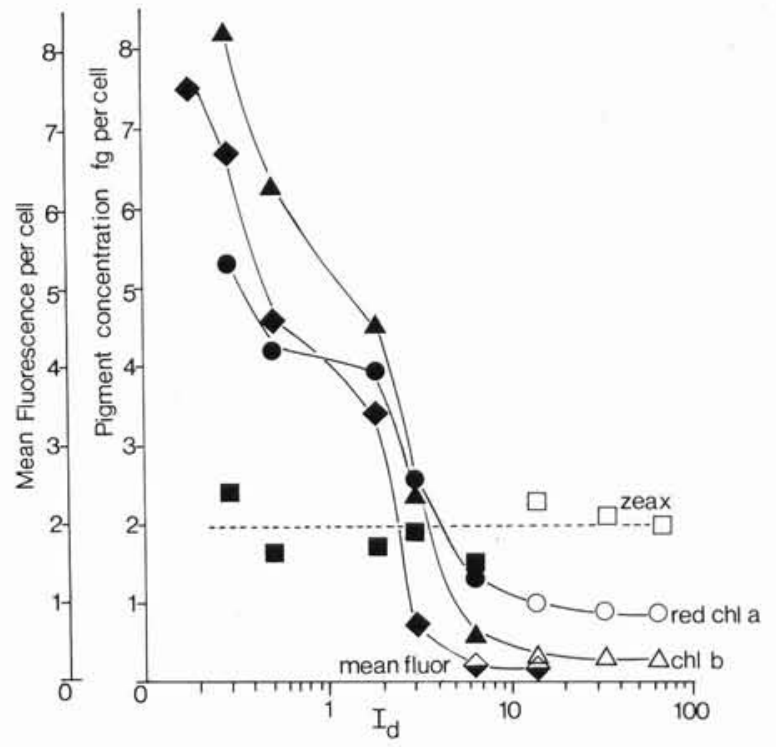

Fig. 5. Estimated cellular content of 'red-shifted' chlorophyll $a$ (red chl a), chlorophyll $b$ (chl b) and zeaxanthin (zeax) of the prochlorophytes. Filled symbols represent measured data, open symbols are data calculated on the basis of indirect estimation of cell numbers (see text). Mean red fluorescence of prochlorophytes (arbitrary units calculated from flow-cytometer data and converted from logarithmic to linear scale) versus percentage of surface irradiance $\left(\mathrm{I}_{0}\right)$. Half-open symbols are data where only part of the population could be detected with flow-cytometry

shifted' chlorophyll $a$ and chlorophyll $b$ content of the cells increase with decreasing growth irradiance. 'Redshifted' chlorophyll a increases 5.9 -fold, from 0.91 near the surface to $5.4 \mathrm{fg} \mathrm{cell}^{-1}$ at $0.3 \%$ incident irradiance level, while chlorophyll $b$ increases 18.7 -fold, from 0.44 to $8.2 \mathrm{fg} \mathrm{cell}^{-1}$. In addition, the flow-cytometrically obtained mean red fluorescence signal of the prochlorophytes increases 31.3 -fold, from 0.24 at the surface to 7.5 at the $0.2 \% \mathrm{I}_{0}$ level. The relationship between the red fluorescence signal and the cellular chlorophyll content was a linear one: mean red fluorescence $=1.774$ ('red-shifted' chl $a+\operatorname{chl} b)+$ $2.060 ; \mathrm{r}=0.9836, \mathrm{p}<0.0005, \mathrm{n}=6$ ). So, the size of the red fluorescence signal of the algal cell generated using flow cytometry is proportional to its chlorophyll content. The present data also suggest that 'pigment package' effects, which occur with depth, are minimal for prochlorophytes.

The function of zeaxanthin is a matter of dispute. To date at least 4 taxonomically different groups of marine algae are known to possess higher or lower amounts of this carotenoid (prochlorophytes, chlorophytes, prasinophytes and cyanobacteria; Chisholm et al. 1988, Hooks et al. 1988). Zeaxanthin is a component of a rapid xanthophyll cycle, showing a light-dependent periodicity, with maximal values in the light period and 
minimal values during the dark period (Kohata \& Watanabe 1989). Because of the spatial separation from the other pigments in cyanobacteria (Omata \& Murata 1983, Resch \& Gibson 1983), its role in photosynthetic energy transfer should be limited (Siefermann-Harms 1985, Wasielewski et al. 1986). Its function of a photoprotective agent seems therefore feasible (Pearl 1984, Kana et al. 1988, Demmig-Adams 1989). In contrast, we observed a nearly constant zeaxanthin value for the prochlorophytes over the growth irradiance. Taking in consideration that our samples were taken predawn possible light effects can be excluded. The measured concentrations would therefore represent the minimal values for zeaxanthin.

It is clear that the picoplanktonic prochlorophyte containing a 'red-shifted' chlorophyll $a$ is not only a common but also an abundant feature in the (sub)tropical oceans. To what extent the poorly pigmented cells in the upper part of the euphotic zone have physiological properties that differ from more densely pigmented cells found at the bottom of the euphotic zone is open to further research.

Acknowledgements. We acknowledge the captain and crew of the RV 'Tyro', technicians from our Institute and Wayne Reese for assistance during and prior to the cruise; special thanks is given to the chief scientist Hein de Baar, for organizing this cruise. The nutrient data were provided by Rob de Vries and Karel Bakker. We thank Dr Winfried Gieskes for his revision of a earlier draft of this manuscript and Prof. S. Chisholm for her helpful comments.

\section{LITERATURE CITED}

Abaychi, J. K., Riley, J, P. (1979). The determination of phytoplankton pigments by high-performance liquid chromatography. Analytica chim. Acta 107: 1-911

Alberte, R. S., Wood, A. M., Kursar, T. A., Guillard, R. R. L. (1984). Novel phycoerythrins in marine Synechococcus spp. Characterization and evolutionary and ecological implications. Plant Physiol. 75: 732-739

Bidigare, R. R., Schoffield, O., Prézelin, B. B. (1989). Influence of zeaxanthin on quantum yield of photosynthesis of Synechococcus clone WH7803 (DC2). Mar. Ecol. Prog. Ser. 56: $177-188$

Burger-Wiersma, T., Veenhuis, M., Korthals, H. J., van der Wiel, C. C. M., Mur, L. R. (1986). A new prokaryote containing chlorophylls $a$ and $b$. Nature, Lond. 320: 262-264

Burkill, P. (1987). Analytical flow cytometry and its application to marine microbial ecology. In: Sleight, M. A. (ed.) Microbes in the sea. Ellis Horwood Ltd, Chichester, p. 139-166

Campbell, L., Iturriaga, R. (1988). Identification of Synechococcus spp. in the Sargasso Sea by immunofluorescence and fluorescence excitation spectroscopy performed on individual cells. Limnol. Oceanogr. 33: 1196-1201

Chisholm, S. W., Olson, R. J., Zettler, E. R., Goericke, R., Waterbury, J. B., Welschmeyer, N. A. (1988). A novel freeliving prochlorophyte abundant in the oceanic euphotic zone. Nature, Lond. 334: 340-343
Cuhel, R. L., Waterbury, J. B. (1984). Biochemical composition and short-term nutrient incorporation patterns in a unicellular marine cyanobacterium, Synechococcus (WH7803). Limnol. Oceanogr. 29: 370-374

Demmig-Adams, B. (1989). LichtstreB und Lichtschutz bei Pflanzen. Naturwissenschaften 76: 262-267

Foss, P., Guillard, R. R. L., Liaaen-Jensen, S. (1984). Prasinoxanthin - a chemosystematic marker for algae. Phytochem. 23: 1629-1633

Gieskes, W. W. C., Kraay, G. W. (1983). Unknown chlorophyll a derivatives in the North Sea and the tropical Atlantic Ocean revealed by HPLC analysis. Limnol. Oceanogr. 28: 757-766

Gieskes, W. W. C., Kraay, G. W. (1986). Floristic and physiological differences between the shallow and the deep nanoplankton community in the euphotic zone of the open tropical Atlantic revealed by HPLC analysis of pigments. Mar. Biol. 91: 567-676

Gieskes, W. W. C., Kraay, G. W., Nontji, A., Setiapermana D., Sutomo (1988). Monsoonal alternation of a mixed and layered structure in the phytoplankton of the euphotic zone of the Banda Sea (Indonesia): a mathematical analysis of the algal pigment fingerprints. Neth. J. Sea Res. 22: $123-137$

Gieskes, W. W. C., Kraay, G. W., Tijssen, S. B. (1978). Chlorophylls and their degradation products in the deep pigment maximum layer of the tropical North Atlantic. Neth. J. Sea Res. 12: 195-204

Guillard, R. R. L., Murphy, L. S., Foss, P., Liaaen-Jensen, S. (1985). Synechococcus spp. as likely zeaxanthin-dominant ultraplankton in the North Atlantic. Limnol. Oceanogr. 30: $412-414$

Hooks, C. E., Bidigare, R. R., Keller, M. D., Guillard, R. R. L. (1988). Coccoid eukaryotic marine ultraplankters with four different HPLC pigment signatures. J. Phycol. 24: $571-580$

Jeffrey, S. W. (1968). Quantitative thin-layer chromatography of chlorophylls and carotenoids from marine algae. Biochem. Biophys. Acta 162: 271-285

Johnson, P. W., McN Sieburth, J. (1982). In-situ morphology and occurrence of eucaryotic phototrophs of bacterial size in the picoplankton of estuarine and oceanic waters. J. Phycol. 18: 318-327

Kana, T. M., Glibert, P. M., Goericke, R., Welschmeyer, N. A. (1988). Zeaxanthin and $\beta$-carotene in Synechococcus WH7803 respond differently to irradiance. Limnol. Oceanogr. 33: 1623-1627

Kohata, K., Watanabe, M. (1989). Diel changes in the composition of photosynthetic pigments and cellular carbon and nitrogen in Pyramimonas parkeae (Prasinophyceae). J. Phycol. 25: 377-385

Olson, R. J., Chisholm, S. W., Zettler, E. R., Altabet, M. A., Dusenberry, J. A. (1990). Spatial and temporal distribution of prochlorophyte picoplankton in the North Atlantic Ocean. Deep Sea Res. (in press)

Olson, R. J., Vaulot, D., Chisholm, S. W. (1985). Marine phytoplankton distributions measured using shipboard flow cytometry. Deep Sea Res. 32: 1273-1280

Omata, T., Murata, N. (1983). Isolation and characterization of the cytoplasmic membranes from the blue-green alga (cyanobacterium) Anacystis nidulans. Plant Physiol. 24: 1101-1112

Pearl, H. W. (1984). Cyanobacterial carotenoids: their roles in maintaining optimal photosynthesis production among aquatic bloom-forming genera. Oecologia (Berl.) 61: 143-149

Resch, C. M., Gibson, J. (1983). Isolation of the carotenoid 
containing cell wall of three unicellular cyanobacteria. J. Bact. 155: 345-350

Shapiro, L. P., Haugen, E. M., Keller, M. D., Bidigare, R. R., Campbell, L., Guillard, R. R. L. (1989). Taxonomic affinities of marine coccoid ultraplankton: a comparison of immunochemical surface antigen cross-reactions and HPLC chloroplast pigment signatures. J. Phycol. 25: 794-797

Siefermann-Harms, D. (1985). Carotenoids in photosynthesis. 1. Location in photosynthetic membranes and light-harvesting function. Biochem. Biophys. Acta 811: 325-355

Stockner, J. G. (1988). Phototropic picoplankton: an overview from marine and freshwater ecosystems. Limnol. Oceanogr. 33: 765-775

This article was submitted to the editor
Stockner, J. G., Antia, N. J. (1986). Algal picoplankton from marine and freshwater ecosystems: a multidisciplinary perspective. Can. J. Fish. Aquat. Sci. 43: 2472-2503

Strathmann, R. R. (1967). Estimating the organic carbon content of phytoplankton from cell volume or plasma volume. Limnol. Oceanogr. 12: 411-418

Takahashi, M., Hori, T. (1984). Abundance of picophytoplankton in the subsurface chlorophyll maximum layer in subtropical and tropical waters. Mar. Biol. 79: 177-186

Wasielewski, M. R., Lindell, P. A., Barrett, D., Moore, T., Gust, D. (1986). Ultrafast carotenoid to pheophorbide energy transfer in a biometric model for antenna function in photosynthesis. Nature, Lond. 322: 570-572

Manuscript first received: March 2, 1990

Revised version accepted: August 14, 1990 